\title{
The Teaching of Intercultural Communicative Competence in China: How Much Help Do Coursebooks Provide?
}

\author{
John Harper \\ Language and Culture Center, Duke Kunshan University, Kunshan, China \\ Email: john.harper@dukekunshan.edu.cn
}

How to cite this paper: Harper, J. (2020) The Teaching of Intercultural Communicative Competence in China: How Much Help Do Coursebooks Provide?. Open Journal of Modern Linguistics, 10, 647-664. https://doi.org/10.4236/ojml.2020.106040

Received: October 19, 2020

Accepted: November 16, 2020

Published: November 19, 2020

Copyright $\odot 2020$ by author(s) and Scientific Research Publishing Inc. This work is licensed under the Creative Commons Attribution International License (CC BY 4.0)

http://creativecommons.org/licenses/by/4.0/ (c) (i) Open Access

\begin{abstract}
This article reports on the findings of a materials analysis of China-published English as a Foreign Language (EFL) coursebooks dedicated to instruction in Intercultural Communicative Competence (ICC). Starting from an acknowledgement of the reality that EFL teachers tend not to be specifically trained in the area of Intercultural Communication, the article argues that, due to this reality, coursebooks aimed at ICC instruction need to provide a great deal of guidance to classroom teachers. A framework for analyzing ICC-related coursebooks is provided. Afterwards, three readily available, China-published coursebooks are analyzed in terms of the learning tasks provided therein, with learning content, learning process, and participation dynamic being focused upon. Strengths and weaknesses of each of the analyzed coursebooks are noted. Comparisons are made where applicable. Finally, recommendations for classroom teachers are shared.
\end{abstract}

\section{Keywords}

English as a Foreign Language, Intercultural Communication, Intercultural Communicative Competence, Learning Tasks, Materials Analysis

\section{Introduction}

In publications related to English language teaching (ELT), there is currently no shortage of advocates of consciously including a culture component in the curriculum. Pulverness and Tomlinson (2013) argue that teaching approaches that overlook the culture element are "fundamentally flawed" (p. 444). Kramsch (1993), in claiming that "[c]ulture in language learning is not an expendable fifth skill" (p. 1), gives the culture element a status equal to that of the traditional four skills of speaking, listening, reading, and writing. She notes that culture, with all of its 
complexities, challenges learners' "ability to make sense of the world around them" and may in fact "unsettle" hardworking language learners in their quest to acquire the language (p. 1). The challenging and intriguing nature of the culture element, incidentally, is viewed as having a motivating effect on learners. Dörnyei and Kubanyiova (2014), for example, note that the presence of the culture element in the classroom may serve as one of the factors that aid learners in maintaining their motivation during the arduous process of language learning (see also Dörnyei, 2001). Given the current focus on the culture element in ELT, one is not surprised to find that this component of language teaching appears, albeit in a limited fashion, in the Chinese College English Curriculum Requirements (2007).

The culture component, many would argue, should revolve around the teaching of Intercultural Communicative Competence (ICC) - that is, the "ability to ensure a shared understanding by people of different social identities, and [the] ability to interact with people as complex human beings with multiple identities and their own individuality" (Byram, Gribkova, \& Starkey, 2002: p. 5). Curiously enough, commentators have noted that English teachers may lack precisely the skills required to teach ICC. Language teachers, after all, are not trained anthropologists, and they themselves may never have had formal instruction in the area of intercultural communication (Byram \& Kramsch, 2008; Snow, 2015). Commenting specifically on ELT in the Chinese context, Han and Song (2011) state that teachers tend to have only "vague perceptions of ICC" (p. 177). More recently, $\mathrm{Li}$ (2016) has concluded that teachers in China have only a "rough idea" of what the culture component of language teaching should be (p. 771).

It is precisely due to this lack of knowledge of ICC that effective coursebooks are necessary. If language teachers cannot automatically be assumed to be well versed in matters of intercultural communication, the adoption of a well-designed, user-friendly coursebook may be seen as one step toward offsetting such a shortcoming. Granted, coursebooks cannot replace a teacher's role as "creative decision-maker" (Nunan, 1988: p. 99; see also Prabhu, 1987). In fact, as McGrath (2013) points out, the coursebook serves best not as a determinant of course content but rather as a resource. Nevertheless, research has revealed that the coursebook often plays a significant role in determining the ELT curriculum (see Guerrettaz \& Johnston, 2013). And even when it is limited to its place as a resource, it may provide teachers with a useful guide in developing and sequencing a course (see Allen, 2015; Hutchinson \& Torres, 1994; McGrath, 2013; Richards, 1998). Hence, the present study seeks to analyze often-used, China-published, English as a Foreign Language (EFL) coursebooks on intercultural communication with an eye toward determining the type of guidance given to EFL teachers tasked with instructing their students in the area of ICC.

\section{Literature Review}

\subsection{Difficulty of Determining Content in ICC Instruction}

It is probably safe to say that, for most language learners, developing ICC is a li- 
felong process, with progress being made in increments but with complete competence remaining an ongoing pursuit (see Coperías Aguilar). For this reason, the task of narrowing down the vast amount of possible ICC-related material to a limited amount that is teachable in a university EFL course is a daunting one. The difficulty of the task becomes even more obvious when one recognizes that instruction in ICC must compete with instruction oriented around the development of the traditional language skills (see Snow, 2015; Spencer-Oatey \& Franklin, 2009). Clearly, then, some subjective decisions concerning what should be (and what can be) included in ICC instruction need to be made. While disagreements concerning subjective decisions are sure to occur, a review of intercultural communication literature suggests that three aspects of ICC may be prioritized: 1) a focus on skills and habits as opposed to culture learning, 2) a reflection on and analysis of one's own culture, 3) an inclusion of various other cultures as opposed to one target culture.

\subsection{Skills and Habits as Opposed to Culture Learning}

Snow (2015) makes a distinction between culture learning and intercultural competence. The former emphasizes the learning of facts about a particular culture; the latter emphasizes a process "based at least as heavily on skills and habits as on knowledge" (p. 286). Reports indicate that culture learning is much more common in language education. Spencer-Oatey and Franklin (2009), in analyzing data from 12 European countries, found that curricula focused much more on culture knowledge than on skills and habits. Partly as a result of this finding, the authors conclude that ICC development within language programs "probably leaves much to be desired" (p. 238).

Arguments in favor of teaching skills and habits as opposed to factual knowledge abound. The first of these arguments stems from the well-recognized trend toward globalization. The acquisition of facts about a particular culture may benefit a learner who visits that culture. Nevertheless, as Harper (2019) points out, "Given current trends toward globalization, ... a student may very well need intercultural communication skills even if he/she never leaves his/her own country" (p. 49). The tendency to associate culture with nation presents another dilemma. Menard-Warwick (2009) notes that "cultural participation can be rooted in regional, ethnic, and religious affiliations-or in membership in subcultural groups that are defined by their practices" (p. 31). Given the presence of such diversity within a nation, materials focusing on culture learning almost inevitably end up emphasizing the dominant group within the nation. A final issue stems from the fact that cultural conventions are not necessarily followed by a member of a culture. As Spencer-Oatey and Franklin (2009) point out, an individual's culture will influence his/her behavior but may not determine it. More importantly, an individual's culture may not determine "his/her interpretations

of the 'meaning' of other people's behavior" (Spencer-Oatey, 2008, cited in Spencer-Oatey \& Franklin, 2009: p. 15). 


\subsection{Reflection on and Analysis of One's Own Culture}

Kramsch (1993) notes that language education has traditionally focused on the culture element only insofar as it relates to a presumed target culture. Going one step further, in an analysis of ELT materials in terms of the teaching of cultural awareness, Pulverness and Tomlinson (2013) point out the lingering of a tradition of "transmitting unmediated facts and information about an implicitly superior 'target' culture" (pp. 443-444). The presumed target cultures in ELT tend to be the United Kingdom and the United States (see Coperías Aguilar, 2007; Baker, 2012; Li, 2016). Given the tendency to focus on these two countries at the exclusion of the learners' own culture, one may easily identify with Pennycook's claims of "material and cultural neo-colonialism in ELT" (Pennycook, 2016: p. 455). And the mere overlooking of the learners' own culture might easily be viewed as an assumption of "an implicitly superior 'target' culture." Hence, Kumaravadivelu (2002) argues that classroom instruction in intercultural communication must take into account the local and the foreign in order to provide a complete picture of cultural reality.

The claim that classroom instruction needs to include a reflection on the students' own culture is justified on many fronts. As mentioned above, learners today require ICC skills even if they never leave their own country. In such cases, as well as in cases in which travel abroad does take place, learners are likely to need not only the language skills but also the own-culture clarity required to discuss their culture with others (McKay, 2000). This awareness, incidentally, should lead learners to recognize, and grapple with, their own cultural biases (see Moeller \& Faltin Osborn, 2014). In doing so, it should help them develop into interculturally sensitive world citizens-that is, citizens with an "ethnorelative orientation" (Perry \& Southwell, 2011: p. 454). It must also be recognized that learning a foreign language has implications for the learners' identity. Kramsch (1993) discusses the "paradox" of having learners discover "their own national, ethnic, and personal identity through a language that is not the one they grew up with" (p. 256). As paradoxical as the situation in EFL classrooms may be, one must take into account the likelihood that the learners' cultural identity is solidified through comparison/contrast with the other (Cortazzi \& Jin, 1999).

\subsection{Inclusion of Various Other Cultures as Opposed to One Target Culture}

As mentioned above, language education has tended to be oriented around a presumed target culture-a culture implicitly viewed as superior to the learners' own culture. The previous subsection of this paper has given various reasons for the incorporation of a reflection on the learners' own culture into instruction designed to promote ICC. Nevertheless, there is still the issue of the presumed target culture. Given the unquestioned existence of English as today's global language, one may easily claim that no one owns English (Widdowson, 1994; see 
also Crystal, 2003). This lack of ownership, incidentally, would seem to rule out the need of a target culture in most ELT classrooms. As Weninger and Kiss (2013) note, "It is no longer desirable or possible to foster target-culture competence...” (p. 695; see also Baker, 2012; Byram \& Masuhara, 2013).

Discussions of the development of ICC almost invariably touch on the need of what, in general, may be called intercultural flexibility, a term which may be defined as the ability to adapt to a variety of intercultural encounters as they occur. Baker (2012), for example, refers to intercultural awareness as the ability to put one's understanding of the influence of culture on communication "into practice in a flexible and context specific manner in real time communication" (p. 66). Byram and Wagner (2018), in defining the intercultural speaker, point to the "complex interplay of ... students' identity in different linguistic and cultural backgrounds" (p. 144). And Canagarajah (2006) argues that "students should learn to shuttle between [speech] communities in contextually relevant ways" (p. 593 , italics as in original). Clearly, then, the inclusion of a variety of cultural representations in ICC instruction may go a long way toward aiding learners in the attainment of intercultural flexibility.

\section{The Study}

\subsection{Theory behind Materials Analysis}

Littlejohn (2011) provides what is arguably the most inclusive account of materials analysis and, in doing so, distinguishes between analysis and evaluation. According to Littlejohn, analysis consists of the practice of looking at materials "as they are" on the assumption that the materials will be used as dictated by the materials themselves (p. 181). This assumption, he acknowledges, is a far cry from what will happen in the classroom as materials will take on a different form once they are interpreted by the teacher and the learners. Nevertheless, the analysis of materials "as they are" allows the analyst to obtain a clear picture of the underlying philosophy behind the materials-that is, of the view of language, of language learning, of teacher/learner roles. The process of obtaining this picture requires the analyst to move through various "levels' of analysis, making more and more inferences, with increasingly subjective judgement" (Littlejohn, 2011: p. 185; see also McGrath, 2002). After completing such an analysis of materials "as they are," the teacher or program designer or administrator is in a position to conduct an evaluation of the materials to determine their suitability (or lack thereof) for his/her particular learners in his/her particular institutional context.

In the framework given by Littlejohn (2011), the major subjective element of analysis is that of the analysis of tasks. In order to account for learning activities that would not fall under the heading of task-based learning and teaching (TBLT), Littlejohn broadens the TBLT definition of task as a meaning-focused, outcome-oriented type of activity. He defines task in the following broad manner: "any proposal contained within the materials for action to be undertaken by the learners, which has the direct aim of bringing about the learning of the for- 
eign language" (p. 188). And he proposes "three key aspects of tasks":

- How: a process through which learners and teachers are to go.

- With whom: classroom participation concerning with whom (if anyone) the learners are to work.

- About what: content that the learners are to focus on (Littlejohn, 2011: p. 189).

Logically, then, in materials analysis, tasks may be analyzed according to the process, the method of participation, and the content that lie therein.

\subsection{Application and Non-Application of Theory to Present Study}

The present study is based largely on Littlejohn's (2011) framework for the analysis of language tasks, with the basic questions of how, with whom, and about what being major focal points. In considering these questions in terms of instruction related to ICC, the analyst recognizes the reality of a classroom in which teachers and learners work together to create their own classroom culture (see Kramsch, 1993; Weninger \& Kiss, 2013). Materials that readily allow for the creation of such a culture through their process, method of participation, and content might be deemed suitable for further consideration in an evaluation of their appropriateness for a particular learning context. Hence, the framework proposed by Littlejohn provides a logical but general guide for the present study.

As the analysis discussed here focuses on instruction regarding ICC, it is of course necessary for a content component regarding the culture element to be included in the analytical framework. The literature related to materials analysis is curiously lacking in such a component. Littlejohn (2011), for example, in discussing the focus of materials, mentions attention to meaning and form; and in discussing content, he mentions "grammar explanations, personal information, fiction, general knowledge and so on" (p. 90). On the other side of the spectrum, the literature related to ICC in language courses has provided suggestions concerning what might be included in these courses (see, for example, Baker, 2012; Snow, 2016). The author of the present study, however, knows of no previous research related specifically to an analysis of EFL coursebooks in terms of ICC instruction. Hence, the present article adds this particular content focus by considering the following: 1) a focus on skills and habits as opposed to culture learning, 2) a reflection on and analysis of one's own culture, 3) an inclusion of various other cultures as opposed to one target culture. The equations are an exception to the prescribed specifications of this template.

\subsection{Textbooks Analyzed and Research Questions}

Using the framework presented above, this study provides an analysis of the following three coursebooks:

- Bridge between Minds. Intercultural Communication (Zhang, 2011)

- Encounters with Westerners. Improving Skills in English and Intercultural Communication (Snow, 2014) 
- Intercultural Communication: A Practical Coursebook(Hu \& Herd, 2006)

The criteria for selecting these texts are fairly simple. The books are readily available on the Chinese market and thus might easily be considered for use in courses focusing on the development of ICC. They are all intended for use in English courses in China at the tertiary level, and they are all aimed at learners of an intermediate level of proficiency. As the books are all published in China by Chinese publishers, they meet the requirements of institutions which stipulate that only nationally published coursebooks may be used.

The following research questions guide the study:

1) To what degree do the coursebooks promote skills and habits over culture learning?

2) To what degree do the coursebooks provide a reflection on and analysis of one's own culture?

3) To what degree do the coursebooks include a variety of other cultures as opposed to one target culture?

4) To what degree do the process and the participation dynamic of the learning tasks in the coursebooks promote the development of ICC?

The analysis deals with each coursebook separately, making comparisons and contrasts where applicable. In each case, a brief overview of the structure of a particular coursebook will be followed by an analysis of the content focus (i.e., the about what focus specified in research questions 1 - 3). Matters concerning the process and the participation dynamic of the tasks will conclude the discussion of each coursebook. Throughout the analysis, strengths and shortcomings are pointed out. However, there is no attempt to promote one coursebook over another. Rather, the goal, as stated in the introduction of this paper, is to determine what kind of guidance is given to EFL teachers in China in terms of instructing their students in ICC.

In carrying out the study, the researcher needed to take care to avoid the dangers of "making general, impressionistic judgements on the materials" (Littlejohn, 2011: p. 211). To avoid such dangers, the investigation process focused on learning tasks (as mentioned previously). Each task within each coursebook was coded according to its content focus, its proposed learning process, and its participation dynamic. Hence, a particular task might be coded as interpretive (i.e., the content requires learners to interpret an intercultural phenomenon), reading based (i.e., the learner is expected to engage in the process of reading in order to obtain information), and individual (i.e., the learner is not asked to interact with the teacher or with his/her classmates in order to carry out the task). On the other hand, if a learner is asked to work with a partner to answer reading comprehension questions, the task content would be labeled as evaluative, the learning process discussion based, the participation dynamic student-student. Through such a coding process, the researcher was able to group tasks according to their respective characteristics. Ultimately, each of the coursebooks analyzed here relied on a relatively small number of different task types, thus making the coding process relatively straightforward. As will be seen below, however, there were 
several cases in which, due to a lack of clarity of instructions, the participation dynamic could not be identified with any certainty.

In reporting on the findings of the study (see "Analysis" section below), the article presents representative samples of tasks. This method of reporting is hardly problematic since, as stated above, no coursebook analyzed here makes use of a large number of task types. In an effort to treat all coursebooks fairly, cases in which one task type alternates with another have been acknowledged (see, for example, Look and Say and Read and Say tasks in Bridge between Minds).

\section{Analysis}

\subsection{Bridge between Minds: Intercultural Communication (Zhang, 2011)}

After introductory units oriented around defining culture, defining communication, and defining intercultural communication, Bridge between Minds offers units oriented around phenomena that vary widely from culture to culture (e.g., nonverbal communication, interpersonal relationships, social interaction customs). The basic structure of the units of the coursebook is the following: 1) attention-getting quotations related to the topic of the unit, 2) a warmup activity (Look and Say or Read and Say), 3) a set of readings with related activities interspersed within, 4) Revision Tasks. The Look and Say activities tend to be pictures for interpretation while the Read and Say activities tend to be critical incidents - that is, reports or stories of unsuccessful or problematic intercultural interactions, with the problem being interpreted by the learners (see Snow, 2015; Spencer-Oatey \& Franklin, 2009). The readings tend to be rather academic in nature (e.g., a discussion of Hofstede's value dimensions, a discussion of the Whorf-Sapir Hypothesis). The activities interspersed within readings vary considerably. The Revision Tasks feature comprehension questions based on the unit readings along with a variety of tasks related to unit material.

Bridge between Minds does not dwell on culture-related facts but rather on culture-related tendencies that promote the building of skills and habits. A couple of activities of various types should reveal this tendency. In the unit on nonverbal communication, a set of diagrams of hand gestures from various cultures is shown, and learners are asked to guess what the gestures mean. Afterwards, a brief explanation of the meaning of the gestures is given. One finds that the gesture of putting the tip of the index finger and the tip of the thumb together to form a circle means "OK" in the United States but is an obscene gesture in Brazil. The point of the activity is not to lead students to memorize cultural differences in hand gestures but to aid them in developing an ethnorelative perspective which recognizes that the same behaviors may mean different things in different cultures. In a critical incident task, students are asked to reflect on why a young American boy fights with his family's Chinese housekeeper whenever the housekeeper wishes to accompany him to kindergarten. The goal of the task 
is to encourage learners to consider the American boy's clearly individualist tendencies and to compare and contrast these tendencies with their own.

Reflection on and analysis of one's own culture is prevalent throughout Bridge between Minds. Such reflection and analysis at times takes the form of questions specifically related to Chinese culture. Hence, after the critical incident (described above) of the young American boy's unwillingness to be accompanied to kindergarten, the coursebook provides the specific question "Would Chinese children in general always fight to be on their own?" (p. 68). At other times, the call for reflection and analysis of one's own culture is more implicit. A case in point would be a critical incident involving the issue of whether or not to interfere in a female work colleague's naïve flirtation with a man who happens to be engaged to another woman. This task intentionally provides no cultural background of the actors in the dilemma, yet learners are asked to state what they would do if they were colleagues of the flirtatious female worker. Lacking the specific cultural details of the actors, learners are led to analyze the situation from the point of view of Chinese culture and/or to challenge espoused cultural norms in favor of their own unique meanings (see Kramsch, 1993).

Bridge between Minds, while including references to a variety of cultures, has American culture as its main representation of the other. Most, though not all, of the critical incidents involve at least one American. In a critical incident oriented toward cultural differences in family values, an American is amused at his adult Iranian friend's extreme deference to his elder brother. In another incident illustrating differences in greeting styles, a Peruvian exchange student in the United States is surprised at the lack of affection shown to her when she arrives at her host family's house. Furthermore, most explanations of cultural phenomena in the coursebook take the United States as a reference point. The concept of cultural attitudes toward personal space, for example, is illustrated with a discussion of typical distances maintained by Americans in various situations (e.g., in business situations, in friendship situations). A similar American focus is found in the discussion of friendship patterns. In short, then, though references are made to a variety of cultures (e.g., that of Iran, that of Peru, as mentioned above), the focal point tends to be the United States, with other cultures providing a comparison to or a contrast with the United States.

The main shortcoming of Bridge between Minds lies in the process and participation dynamic promoted therein. As Tomlinson and Masuhara (2018) point out, "Good layout in materials supports teachers in managing teaching procedures smoothly with structural clarity" (p. 331). In Bridge between Minds, the layout technique of interspersing activities within academic reading texts provides only limited "structural clarity." The importance (or lack thereof) of a particular activity is not readily discernible. Additionally, instructions for activities often (though not always) fail to meet the basic requirement of being "specific about what to do and specific about how to do it" (Tomlinson \& Masuhara, 2018: p. 349). A case in point illustrating these drawbacks is seen in Activity 11 of Chapter 3. In the midst of a discussion of American ideas of equality of op- 
portunity, two short critical incidents related to the topic appear. Learners are told to read the critical incidents and answer the questions based on them. The lack of salience of the activity itself leaves one wondering how much importance the learners are expected to attach to it. And the instructions- "[R]ead the following two passages and try to answer the questions below each one" (p. 72)-leave one wondering if the task is to be completed as individual work or groupwork, as a writing activity or as a speaking activity. Or is it simply something for the learners to ponder as they read about equality of opportunity? Such decisions will clearly have to be made by the teacher.

\subsection{Encounters with Westerners: Improving Skills in English and Intercultural Communication (Snow, 2014)}

Following an introductory unit presenting the concept of intercultural communication, Encounters with Westerners provides units oriented around issues that may have a profound effect on intercultural encounters (e.g., culture shock, ethnocentrism, the ingroup/outgroup distinction). The ten units follow a consistent pattern: 1) Encounter (a critical incident followed by related activities), 2) Intercultural Communication (a reading passage based on the focus of the unit, a presentation of word combinations used in the reading, related activities), 3) Letter to Fran (a critical incident in letter format followed by a response to the letter, a presentation of word combinations used in the letters, related activities), 4) Generalizing about Western Culture (a reading passage presenting a concept related to Western/Chinese cultural differences, a presentation of word combinations used in the reading, related activities), 5) Learning about Other Cultures (tasks such as interviews to be done outside of class). The exact structure presented here does allow for some variation. Unit 3, for example, contains two Encounter sections and no Letter to Fran. Nevertheless, the overall consistency of the units would seem to reflect the author's view that a stable pattern of tasks oriented around overall course goals may aid teachers in planning and may aid students in feeling confident about their course and about their teacher (see Snow, 2006).

Like Bridge between Minds, Encounters with Westerners focuses on cultural tendencies as opposed to culture-related facts, with tendencies being presented in order to build skills and habits. Reading passages serve as a case in point. A passage focusing on the individualism/collectivism dichotomy provides research indicating that Western cultures such as those of the United Kingdom and the United States tend to rank high in scales of individualism while Asian cultures such as those of Thailand and Hong Kong SAR stand out as being much more collectivist in nature. The point is that such differences need to be taken into account in intercultural encounters, and a caveat is added to note that "the difference between individualist and collectivist cultures is relative rather than absolute" (p. 35). Fittingly, the accompanying critical incident-one involving a Chinese student's offer of help being rejected by a visiting Canadian profes- 
sor-presents a puzzling intercultural encounter illustrating Western individualism in a Chinese context. The puzzle revolves around differences in cultural tendencies manifested at the time of the encounter, not around cultural facts.

Like Bridge between Minds, Encounters with Westerners provides extensive opportunities for reflection on and analysis of one's own culture. The numerous critical incidents provided throughout the coursebook all involve Chinese participants. Hence, learners are constantly asked to reflect on the way in which one Chinese person responds to a particular intercultural encounter and to think of other ways in which the same person could respond. In other tasks, learners are asked to think critically about their own culture. Given a statement which posits seniority as the primary factor in determining power in Chinese culture, learners are asked to modify the statement in order to "make it more accurate" (p. 51). Other tasks call for a consideration of one's own culture in light of the other. In carrying out an interview task requiring an interview with a non-Chinese person on the topic of compliments, learners will necessarily be led to compare their own culturally influenced methods of dealing with compliments to those of the other. In terms of providing instruction in ICC, then, one might say that the coursebook offers ample opportunities for learners to develop an awareness of themselves as members of Chinese culture, as members of an intercultural community, and as individuals tasked with developing their own identity within a global context (see Kramsch, 1993).

The main cultural distinction in Encounters with Westerners lies in the distinction between Chinese culture and Western culture. The focus on the former has been discussed in the preceding paragraph. The focus on the latter, a more problematic one, is exemplified in phrases such as "Westerners tend to believe" (p. 34), "In the West" (p. 64), and "Western cultures tend to be" (p. 84). Like Bridge between Minds, Encounters with Westerners makes reference to a great number of national cultures. One finds, for example, that "Thai culture is much looser than Japanese culture" (p. 85) and that "Denmark, New Zealand, and Ireland tend to be more egalitarian than Britain and the US" (p. 49). In spite of these references, a general comparison of Chinese culture and Western culture prevails. While a generalization of Chinese culture (or of any other national culture) might be considered risky (see Kumaravadivelu, 2003), a generalization placing the totality of Western culture into one broad category could be considered as a lapse into stereotyping. Encounters with Westerners covers this potential problem by pointing out that the various Western cultures "do share enough of their ideas in common" to justify a broad categorization and by adding that the learner should "not be satisfied with just knowing a few simple generalizations about other cultures" (p. 14). Nevertheless, it must be acknowledged that the frequent reference to Western culture, along with the coursebook title, could lead learners toward rash generalizations.

Different from Bridge between Minds, Encounters with Westerners provides learners with very clear guidance in terms of process and participation dynamic. As mentioned above, the coursebook uses a consistent format, thus giving 
learners and teachers a clear direction concerning the learning path that is to be undertaken. Equally important is the labeling and guidance provided for each section and subsection of the coursebook. Reading tasks, given under the general heading of Intercultural Communication and titled according to unit topic, are prefaced with pre-reading questions that give learners a purpose. Tasks included under the general heading of Discussion Activities are identified with labels such as Small group task and Survey. Out-of-class tasks are clearly scaffolded. Such scaffolding is evidenced in the assignment (mentioned above) requiring learners to interview non-Chinese people regarding their methods of giving and receiving compliments: Learners are given guiding questions but are also encouraged to create their own questions. In short, the tasks in Encounters with Westerners leave little doubt about the process to be undertaken or the participation dynamic to be used.

\subsection{Intercultural Communication: A Practical Coursebook (Hu \& Herd, 2006)}

While Encounters with Westerners focuses a great deal on broad phenomena impacting intercultural encounters (e.g., culture shock, ethnocentrism, the ingroup/outgroup distinction), Intercultural Communication stresses communication styles. After an introductory unit presenting what intercultural communication is, the coursebook provides units oriented around communication-style differences that may affect one's understanding and/or appreciation of other cultures. Of the nine units in total, two are titled Daily Verbal Communication. These units deal with very practical matters such as greetings, forms of address, and forms of giving and responding to compliments. Other units concentrate on such issues as cross-gender communication styles, negotiation styles, and humor interpretation. The units follow a consistent format: 1) introductory quotations to present the theme, 2) Warm-up Cases (i.e., critical incidents), 3) short readings related to the theme, 4) Exercises (some to be done in class, some to be done out of class). Given the focus on communication styles, one might say that the coursebook emphasizes "solving [practical] problems rather than merely understanding them" (Spencer-Oatey \& Franklin, 2009: p. 213).

As is the case with the other coursebooks analyzed here, Intercultural Communication uses illustrations and explanations of cultural tendencies to develop skills and habits related to ICC. The critical incidents serve as prime examples. In one such task, an Australian male views his dating relationship as being quite casual and unwittingly draws the ire of the girlfriend's father, who is expecting wedding bells. After reading about the situation, learners are asked to consider how they would explain the father's perspective to the Australian and how they would explain the Australian perspective to the father. Such open-ended critical incidents are occasionally replaced with cultural assimilators, a special type of critical incident which, instead of leaving interpretation open for the learner, asks the learner to choose an interpretation from various options, with an explanation being provided after an option has been chosen (see Snow, 2015; 
Spencer-Oatey \& Franklin, 2009). The readings in Intercultural Communication also serve to aid the building of skills and habits. Hence, a discussion of monochronic and polychronic time and a real-life example of a conflict resulting from this difference reveal to learners the need of maintaining flexibility when notions of scheduling and punctuality arise in intercultural encounters.

In keeping with a tendency demonstrated in the previously analyzed coursebooks, Intercultural Communication provides extensive opportunities for learners to reflect on and analyze their own culture. Most, though not all, critical incidents involve at least one Chinese character and thus encourage learners to view some Chinese people's reactions in intercultural encounters and to consider whether or not they would react in the same way. The previously discussed meet-the-parents scenario provides a case in point. Learners are specifically told to decide how they would explain the contrasting cultural attitudes to the participants. Logically, they would also be inclined to consider whether or not they subscribe to the traditional notions of dating held by the girlfriend's father. Additionally, learners are encouraged to explore, on their own, matters of Chinese culture in relation to other cultures. In one instance, they are asked to explore, outside of class time, the differences between invitations in Chinese culture and Western culture and to write a report on the topic. As mentioned above, such comparison/contrast exercises may aid learners in their efforts to discover their own cultural identity (see Coperías Aguilar, 2007; Harper, 2019; Kearney, 2010). Finally, many of the tasks included in the Exercises section of the coursebook lead learners toward both a cultural and an individual reflection and analysis. For example, upon being asked to complete a friendship survey individually and then to discuss their results with their classmates, learners are likely to discover previously unperceived cultural beliefs and values as well as individual differences within their own culture.

The presentation of the other in Intercultural Communication takes on various forms. At times, the coursebook seems to focus on a very broad East/West dichotomy. One finds, for example, the following differentiation between the two: "Eastern and Western perspectives on the universe, nature, knowledge, and time are reflected in specific activities of individuals as they relate themselves to fellow human beings" (p. 191). However, as mentioned above, the coursebook contains a very explicit focus on communication styles. Once the focus shifts specifically to communication styles, the concentration shifts more specifically to the English-speaking world and the Chinese-speaking world, with American culture becoming the focal point of the comparison with Chinese culture. Hence, in a unit sub-section titled "Common Response Formulas of English and Chinese Compliments" (p. 54), one finds reference to "English speakers" (p. 55) and to "English cultures" (p. 56), yet explanations are oriented specifically around American culture. In spite of the above-mentioned foci, it must be acknowledged that references to a large variety of national cultures are included in the coursebook. Some of these references, unfortunately, lapse into stereotypes. One finds, for example, that different ways of reacting to a case of a fly in a beer re- 
veal the inclinations of certain national cultures: "the English's seriousness, the French's arrogance, the Spanish's [sic] generosity, the Japanese's critical approach, the Arab's sarcasm and the American's humor" (p. 21).

Like Encounters with Westerners, Intercultural Communication provides learners with a clear orientation in terms of task process and participation dynamic. The consistent format of the units and the clearly labeled sections guide learners (and no doubt teachers) through the learning process. Learners will quickly recognize that units begin with critical incidents and that the ICC skills needed for completion of these critical incidents will be further elaborated upon in the following readings. Likewise, they will quickly recognize that the readings will be followed by a set of tasks intended to reinforce the readings themselves. As mentioned above, such consistency of format should provide learners with confidence as they work toward reaching course goals (Snow, 2006). Furthermore, instructions throughout the coursebook typically indicate how tasks are to be completed. As a case in point, a frequent task in the Exercises section of the coursebook is that of People Watching. These tasks, all clearly scaffolded with guiding questions, ask learners to engage in the out-of-class experiment of studying people's particular interactional behaviors (e.g., frequency of touching, distance maintenance). Learners are instructed to record the results of their experiment in their learning journals. In short, the instructions meet the requirement of being "specific about what to do and specific about how to do it" (Tomlinson \& Masuhara, 2018: p. 349).

\section{Conclusion}

This article has presented an analysis of three China-published coursebooks oriented around instruction in ICC:

- Bridge between Minds. Intercultural Communication (Zhang, 2011)

- Encounters with Westerners. Improving Skills in English and Intercultural Communication (Snow, 2014)

- Intercultural Communication: A Practical Coursebook (Hu \& Herd, 2006)

As stated earlier, materials analysis concerns a careful consideration of the materials (in this case, coursebooks) "as they are" and hence does not take into account ways in which the materials may undergo transformation due to interpretations of teachers and learners. This separation of the coursebook from the interpretations given to them by teachers and students calls to mind a point made by Coperías Aguilar (2007): “The [course]book is just an object..." (p. 72). Such a comment can hardly be questioned. Coperías Aguilar (2007), incidentally, goes on to say that "textbooks should be challenged" (p. 72). The analysis presented above, then, may be said to consist of a process of challenging the three objects in terms of how, with whom, and about what and thereby challenging them in terms of guidance offered to teachers.

As a starting point toward an overall conclusion of the analysis, one may ask whether or not the coursebooks help create the sort of cultural immersion that is 
often considered impossible in EFL settings (see Kearney, 2010). Kearney (2010), in arguing for a narrative approach to ICC instruction in EFL classrooms, notes that the narrative must lead learners toward the following:

1) gaining access to the frames of reference that others use in interpreting and shaping their individual and collective experience of the world;

2) coming to an awareness of what a point of view is-a kind of cultural tool that mediates our experience of the world;

3) taking on unfamiliar perspectives and attempting to view the world, at least temporarily, through these new lenses;

4) in a reflective movement, denaturalizing one's own familiar cultural perspective and potentially seeing oneself as others do (p. 334).

Clearly, the coursebooks analyzed here provide guidance to the instructor in reaching such goals. The critical incidents, present in all of the coursebooks, reveal different frames of reference and different points of view, thus leading learners to see the world from unfamiliar perspectives and to see themselves from the standpoint of the other. Likewise, relevant readings, also present in all of the coursebooks, specifically point out frames of reference that might be unfamiliar to Chinese learners. In doing so, one may argue, the readings implicitly satisfy the four requirements given above. Finally, tasks particular to the various coursebooks also provide guidance in terms of reaching the four goals. The interview tasks of Encounters with Westerners and the People Watching experiments of Intercultural Communication serve as apt examples.

If Kearney's (2010) stated goals are taken as a benchmark, one must read further into the author's commentary and note that she also points out the following: "Creating a classroom environment that resounds with cultural narratives will require a selection of a variety of representations and texts..." (p. 334). Herein lies a potential shortcoming of all of the previously analyzed coursebooks. One finds a particular American focus in Bridge between Minds and in Intercultural Communication; one finds a rather broad generalization of Western culture in Encounters with Westerners. A concentration on American culture and implicitly on the native speakers of English in that culture denies learners the opportunity to explore the now-common phenomenon of two non-native speakers of English communicating in English (see Byram, 1997). As pointed out earlier, a generalization of Western culture, in spite of a justification of the generalization, has the potential to lead to stereotypes. And when various cultures are mentioned rather incidentally, the danger of stereotyping may increase-as has been noted above with the reference to French "arrogance" in the coursebook Intercultural Communication.

In terms of the question How (i.e., the question related to process and participation), Kearney's (2010) discussion also comes into play. As she points out, "Teachers, too, may need help in learning how to perform ... scaffolding of students' developing interpretations and in finding ways to facilitate their students' taking up other positions..." (p. 335). It has been noted previously that the scaffolding provided in terms of task sequence (i.e., unit structure) and in terms of 
clarity of instructions may play a large role in guiding students along the learning path. Logically, then, coursebooks with clearly structured units and precise instructions (e.g., Encounters with Westerners, Intercultural Communication) provide instructors with the basic foundation needed for them effectively to scaffold learners' ongoing ICC development. Needless to say, such structure and clarity also guide instructors in their course planning. Hence, in trying to reach the four goals provided by Kearney (2010), instructors will be significantly aided when given a coursebook with a clear format and focused task instructions. Encounters with Westerners and Intercultural Communication stand out as logical options in this respect.

If the coursebook is "just an object" to be interpreted and ultimately changed by its users, a crucial implication of this study may be garnered from previously mentioned observations by Han and Song (2011) and Li (2016). These authors, it will be recalled, comment respectively on the "vague perceptions" and the "rough idea" of ICC held by language teachers in China. Such comments, where applicable, point to gaps that need to be filled if coursebooks are to serve their purpose. Granted, coursebooks have the responsibility of providing instructors and students with clear guidance. And it has been shown that the coursebooks analyzed here go far in providing such guidance. Coursebooks, however, will continue to remain imperfect. Language courses, especially English courses, will most likely continue to serve as the principal means through which ICC is taught in China. Logically, then, it would seem that those of us who work primarily as language instructors might need to make a special effort to meet the coursebook halfway.

\section{Conflicts of Interest}

The author declares no conflicts of interest regarding the publication of this paper.

\section{References}

Allen, C. (2015). Marriages of Convenience? Teachers and Coursebooks in the Digital Age. ELT Journal, 69, 249-263. https://doi.org/10.1093/elt/ccv005

Baker, W. (2012). From Cultural Awareness to Intercultural Awareness: Culture in ELT. ELT Journal, 66, 62-70. https://doi.org/10.1093/elt/ccr017

Byram, K., \& Kramsch, C. (2008). Why Is It So Difficult to Teach Language as Culture? The German Quarterly, 81, 20-34. https://doi.org/10.1111/j.1756-1183.2008.00005.x

Byram, M. (1997). Teaching and Assessing Intercultural Communicative Competence. Clevedon: Multilingual Matters.

Byram, M., \& Masuhara, H. (2013). Intercultural Competence. In B. Tomlinson (Ed.), Applied Linguistics and Materials Development (pp. 143-162). London: Bloomsbury. https://doi.org/10.1002/9781405198431.wbeal0554

Byram, M., \& Wagner, M. (2018). Making a Difference: Language Teaching for Intercultural and International Dialogue. Foreign Language Annals, 51, 140-151.

https://doi.org/10.1111/flan.12319 
Byram, M., Gribkova, B., \& Starkey, H. (2002). Developing the Intercultural Dimension in Language Teaching: A Practical Introduction for Teachers [Electronic Version]. https://core.ac.uk/display/111018814

Canagarajah, A. S. (2006). The Place of World Englishes in Composition: Pluralization Continued. College English Composition and Communication, 57, 586-619.

Chinese Ministry of Education (2007). College English Curriculum Requirements. Beijing: Tsinghua University Press.

Coperías Aguilar, M. J. (2007). Dealing with Intercultural Communicative Competence in the Foreign Language Classroom. In E. Alcón Soler, \& M. P. Safont Jordà (Eds.), In tercultural Language Use and Language Learning (pp. 59-78). Dordrecht: Springer. https://doi.org/10.1007/978-1-4020-5639-0_4

Cortazzi, M., \& Jin, L. (1999). Cultural Mirrors: Materials and Methods in the EFL Class room. In E. Hinkel (Ed.), Culture in Second Language Teaching and Learning (pp. 196-219). Cambridge: Cambridge University Press.

Crystal, D. (2003). English as a Global Language. Cambridge, UK: Cambridge University Press. https://doi.org/10.1017/CBO9780511486999

Dörnyei, Z. (2001). Motivational Strategies in the Language Classroom. Cambridge: Cambridge University Press. https://doi.org/10.1017/CBO9780511667343

Dörnyei, Z., \& Kubanyiova, M. (2014). Motivating Learners, Motivating Teachers: Building Vision in the Classroom. Cambridge: Cambridge University Press.

Guerrettaz, A. M., \& Johnston, B. (2013). Materials in the Classroom Ecology. The Modern Language Journal, 97, 779-796. https://doi.org/10.1111/j.1540-4781.2013.12027.x

Han, X., \& Song, L. (2011). Teacher Cognition of Intercultural Communicative Competence in the Chinese ELT Context. Intercultural Communication Studies, 20, 175-192.

Harper, J. (2019). A Text-Driven, Task-Based Approach to the Design of Materials for Teaching Intercultural Communicative Competence. Journal of English Language Teaching and Linguistics, 4, 47-66. https://doi.org/10.21462/jeltl.v4i1.187

Hu, C., \& Herd, B. J. (2006). Intercultural Communication: A Practical Coursebook. Beijing: Foreign Language Teaching and Research Press.

Hutchinson, T., \& Torres, E. (1994). The Textbook as Agent of Change. ELT Journal, 48, 315-328. https://doi.org/10.1093/elt/48.4.315

Kearney, E. (2010). Cultural Immersion in the Foreign Language Classroom: Some Narrative Possibilities. The Modern Language Journal, 94, 332-336.

https://doi.org/10.1111/j.1540-4781.2010.01028.x

Kramsch, C. (1993). Context and Culture in Language Teaching. Oxford: Oxford University Press.

Kumaravadivelu, B. (2002). Paying Attention to Inter-In Intercultural Communication. TESOL Journal, 11, 3-4.

Kumaravadivelu, B. (2003). Problematizing Cultural Stereotypes in TESOL. TESOL Quarterly, 37, 709-719. https://doi.org/10.2307/3588219

Li, Y. (2016). Intercultural Awareness in Foreign Language Teaching: A Chinese Perspective. Journal of Language Teaching and Research, 7, 768-772.

https://doi.org/10.17507/jltr.0704.18

Littlejohn, A. (2011). The Analysis of Language Teaching Materials: Inside the Trojan Horse. In B. Tomlinson (Ed.), Materials Development in Language Teaching (2nd ed., pp. 179-211). Cambridge: Cambridge University Press.

McGrath, I. (2002). Materials Evaluation and Design for Language Teaching. Edinburgh: 
Edinburgh University Press.

McGrath, I. (2013). Teaching Materials and the Role of EFL/ESL Teachers: Practice and Theory. London: Bloomsbury.

McKay, S. L. (2000). Teaching English as an International Language: Implications for Cultural Materials in the Classroom. TESOL Journal, 9, 7-11.

Menard-Warwick, J. (2009). Co-Constructing Representations of Culture in ESL and EFL Classrooms: Discursive Faultlines in Chile and California. The Modern Language Journal, 93, 30-45. https://doi.org/10.1111/j.1540-4781.2009.00826.x

Moeller, A. J., \& Faltin Osborn, S. R. (2014). A Pragmatist Perspective on Building Inter cultural Communicative Competency: From Theory to Classroom Practice. Foreign Language Annals, 47, 669-673. https://doi.org/10.1111/flan.12115

Nunan, D. (1988). The Learner-Centred Curriculum. Cambridge, UK: Cambridge University Press. https://doi.org/10.1017/CBO9781139524506

Pennycook, A. (2016). Critical Approaches to Language Teaching. Shanghai: Shanghai Foreign Language Education Press.

Perry, L. B., \& Southwell, L. (2011). Developing Intercultural Understanding and Skills: Models and Approaches. Intercultural Education, 22, 453-466.

https://doi.org/10.1080/14675986.2011.644948

Prabhu, N. S. (1987). Second Language Pedagogy. Oxford: Oxford University Press.

Pulverness, A., \& Tomlinson, B. (2013). Materials for Cultural Awareness. In B. Tomlinson (Ed.), Developing Materials for Language Teaching (2nd ed., pp. 443-459). London: Bloomsbury.

Richards, J. C. (1998). Beyond Training. Cambridge, UK: Cambridge University Press.

Snow, D. (2006). More Than a Native Speaker: An Introduction to Teaching English Abroad (revised edition). Alexandria, VA: TESOL Press.

Snow, D. (2014). Encounters with Westerners: Improving Skills in English and Intercultural Communication. Shanghai: Shanghai Foreign Language Education Press.

Snow, D. (2015). English Teaching, Intercultural Competence, and Critical Incident Exercises. Language and Intercultural Communication, 15, 285-299. https://doi.org/10.1080/14708477.2014.980746

Snow, D. (2016). Affective Factors and Interpretive Judgments in Intercultural Encounters. Intercultural Communication Studies, 25, 19-32.

Spencer-Oatey, H. (2008). Introduction. In H. Spencer-Oatey (Ed.), Culturally Speaking: Culture, Communication and Politeness Theory (2nd ed., pp. 1-8). London: Continuum.

Spencer-Oatey, H., \& Franklin, P. (2009). Intercultural Interaction: A Multidisciplinary Approach to Intercultural Communication. London: Palgrave Macmillan. https://doi.org/10.1057/9780230244511

Tomlinson, B., \& Masuhara, H. (2018). The Complete Guide to the Theory and Practice of Materials Development for Language Teaching. Hoboken, NJ: Wiley Blackwell.

Weninger, C., \& Kiss, T. (2013). Culture in English as a Foreign Language (EFL) Text-Books: A Semiotic Approach. TESOL Quarterly, 47, 694-716. https://doi.org/10.1002/tesq.87

Widdowson, H. G. (1994). The Ownership of English. TESOL Quarterly, 28, 377-389. https://doi.org/10.2307/3587438

Zhang, A.-L. (2011). Bridge between Minds: Intercultural Communication. Chongqing: Chongqing University Press. 